\title{
Enhanced Flotation Recovery of Fine Molybdenite Particles Using a Coal Tar-Based Collector
}

\author{
Yande Chao ${ }^{1}$, Shulei $\mathrm{Li}^{2, *}$, Lihui Gao ${ }^{3, *}$, Lijuan Sun ${ }^{4}$, Lingni $\mathrm{Li}^{4}{ }^{4}$ Na Chai ${ }^{4}$ and Yijun Cao ${ }^{2,5}$ \\ 1 Luanchuan Longyu Molybdenum Mining Co., Ltd., Luoyang 471500, China; ydchao-cumt@163.com \\ 2 National Engineering Research Center of Coal Preparation and Purification, \\ China University of Mining \& Technology, Xuzhou 221116, China; caoyj@cumt.edu.cn \\ 3 School of Environment Science and Spatial Informatics, China University of Mining \& Technology, \\ Xuzhou 221116, China \\ 4 School of Chemical Engineering and Technology, China University of Mining \& Technology, \\ Xuzhou 221116, China; sunlijuan@cumt.edu.cn (L.S.); lingnili@163.com (L.L.); chaina0122@163.com (N.C.) \\ 5 School of Chemical Engineering, Zhengzhou University, Zhengzhou 450001, China \\ * Correspondence: lishulei2007@cumt.edu.cn (S.L.); lihuigaocumt@163.com (L.G.)
}

check for

updates

Citation: Chao, Y.; Li, S.; Gao, L.; Sun, L.; Li, L.; Chai, N.; Cao, Y. Enhanced Flotation Recovery of Fine Molybdenite Particles Using a Coal Tar-Based Collector. Minerals 2021, 11, 1439. https://doi.org/10.3390/ $\min 11121439$

Academic Editors: Zhiyong Gao, Wenjihao Hu, Peipei Wang, Kirsten Claire Corin and Ljudmilla Bokányi

Received: 10 November 2021 Accepted: 11 December 2021 Published: 20 December 2021

Publisher's Note: MDPI stays neutral with regard to jurisdictional claims in published maps and institutional affiliations.

Copyright: (c) 2021 by the authors. Licensee MDPI, Basel, Switzerland. This article is an open access article distributed under the terms and conditions of the Creative Commons Attribution (CC BY) license (https:/ / creativecommons.org/licenses/by/ $4.0 /)$.

\begin{abstract}
Low flotation efficiency has always been a problem in the separation of low-grade molybdenum ores because of the finely disseminated nature and crystal anisotropy of molybdenite. In this study, a novel kerosene-coal tar collector (KCTC) was prepared and used to explore the feasibility of improving the recovery of fine molybdenite particles. The results showed that KCTC achieved better attaching performance than that shown by kerosene, and the surface coverage and attaching rate constant were improved significantly, especially for finer particles of $-38+20 \mu \mathrm{m}$. Compared with kerosene, KCTC showed more affinity for molybdenite particles and greater adsorbed amounts of KCTC on molybdenite particles were achieved. Moreover, the composite collector was shown to float single molybdenite particles of different sizes, and it was found that the recovery of molybdenite particles of different sizes, particularly in the case of those at $-20 \mu \mathrm{m}$, was improved dramatically by KCTC. The flotation results of actual molybdenum ores further confirmed that KCTC was beneficial to flotation recovery and the selectivity of molybdenite. This indicated that KCTC is a potential collector for the effective flotation of low-grade deposits of molybdenum ores, and more studies should be conducted on further use in industrial practice.
\end{abstract}

Keywords: molybdenite; attaching kinetics; coal tar; flotation

\section{Introduction}

Molybdenum is an important metal with a wide range of applications in metallurgy, the chemical industry, etc. [1,2]. Molybdenite is the principal mineral in molybdenum extraction, and it is recovered from Mo-Cu ores or molybdenum ores using the froth flotation technique [3-5]. However, molybdenite is an anisotropic mineral with two types of surfaces. The nonpolar and hydrophobic faces are generated by the breaking of van der Waals forces between S-Mo-S layers, while the polar and hydrophilic edges are formed by the rupture of strong covalent Mo-S bonds [6]. As high-grade ore deposits are depleted, it is becoming ever more urgent to effectively process the low-grade deposits, where low-grade ores of a finely disseminated nature require finer grinding for liberation, resulting in poor floatability. Nonpolar hydrocarbon oils (saturated hydrocarbons) such as diesel oil, kerosene and transformer oil are used as the most common collectors for molybdenite flotation [7-10]. Nevertheless, they have more affinity for the nonpolar faces of molybdenite, created by van der Waals forces and hydrophobic forces [11-13], rather than for the polar edges. The hydrophobicity of edge surfaces cannot be improved, which results in poor floatability.

As reported, mixed collectors have been widely used to enhance the flotation performance of minerals [14-17]. A mixture of KAX and DDA was used to separate smithsonite 
and the recovery rate increased dramatically compared with either KAX or DDA in isolation. The presence of KAX increased lateral tail-tail hydrophobic bonds, which resulted in more hydrophobic smithsonite [14]. Excellent separation of lepidolite from quartz at a neutral $\mathrm{pH}$ was achieved with a mixed collector of SOL/DDA, due to the larger contact angle of lepidolite than quartz [18]. Additionally, a combination of aliphatic hydrocarbon oil and liquid polycyclic aromatic hydrocarbon was prepared and enhanced the floatability of fine molybdenite particles, especially for the finer particles [19]. Recently, methylnaphthalene and naphthalene were used as auxiliary collectors with kerosene at a mass ratio of 5:95 to improve the flotation performance of molybdenum ores; Mo recovery was increased by $3-4 \%$ due to the principle of similar compatibility of surface energy [1]. Hence, the mixed collectors of aromatic and saturated hydrocarbons were beneficial to the flotation of fine molybdenite particles. Recently, more attention has been paid to the comprehensive utilization of coal tar as a result of the fast development of the coal chemical industry. It is well known that coal tar is a complex mixture of aromatic hydrocarbons including polycyclic and heterocyclic compounds and fused ring compounds [20] that has the potential to be a candidate as a collector to enhance the flotation of fine-grained molybdenite. If coal tar is applied as an auxiliary collector in the separation of molybdenite from Mo-Cu ores or molybdenum ores, it can not only achieve the effective flotation of finely disseminated molybdenite but also decrease the collector cost in flotation due to the higher price of nonpolar hydrocarbon oils and lower price of coal tar. Moreover, a new strategy can be proposed for the utilization of coal tar. However, few reports have been published on the application of coal tar in flotation and more studies should be conducted for the flotation of molybdenite [20]. Therefore, in this paper, the influence of coal tar on the flotation performance of fine-grained molybdenite of different sizes was explored and the underlying mechanism was revealed.

\section{Materials and Methods}

\subsection{Materials}

The molybdenite block raw ores of a high grade were obtained from a molybdenum mine in Jiangxi Province, China. The samples were crushed into small pieces and then purified using a shaking table. The concentrate was further crushed and then ground. As shown in Table 1 and Figure 1, the molybdenite particles were relatively pure. Finally, the ground-down molybdenite particles were screened to obtain samples with a size of $-20 \mu \mathrm{m}$, $-38+20 \mu \mathrm{m}$ and $-74+38 \mu \mathrm{m}$, respectively. The actual molybdenum ores were obtained from the tailings of rougher particle flotation processes, produced by the Luanchuan Xinxin Mining Co. Ltd., Luoyang, Henan Province, China. As shown in Figure 2, the $\mathrm{D}_{50}$ was $20.19 \mu \mathrm{m}$ and the $\mathrm{D}_{75}$ was $38.46 \mu \mathrm{m}$. This indicated that the molybdenum ores should be ground down to finer particles to liberate the molybdenite. The chemical analysis of the molybdenum ores is given in Table 2 .

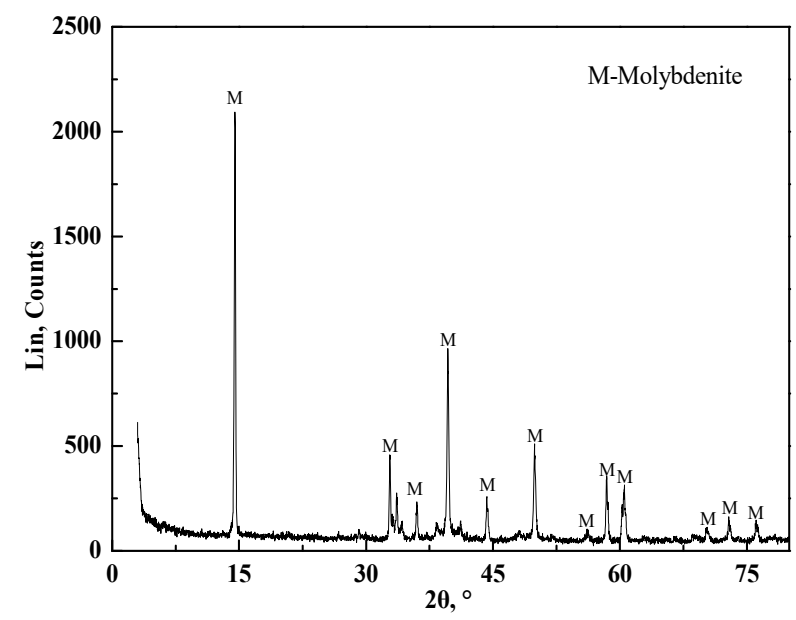

Figure 1. XRD analysis of molybdenite. 


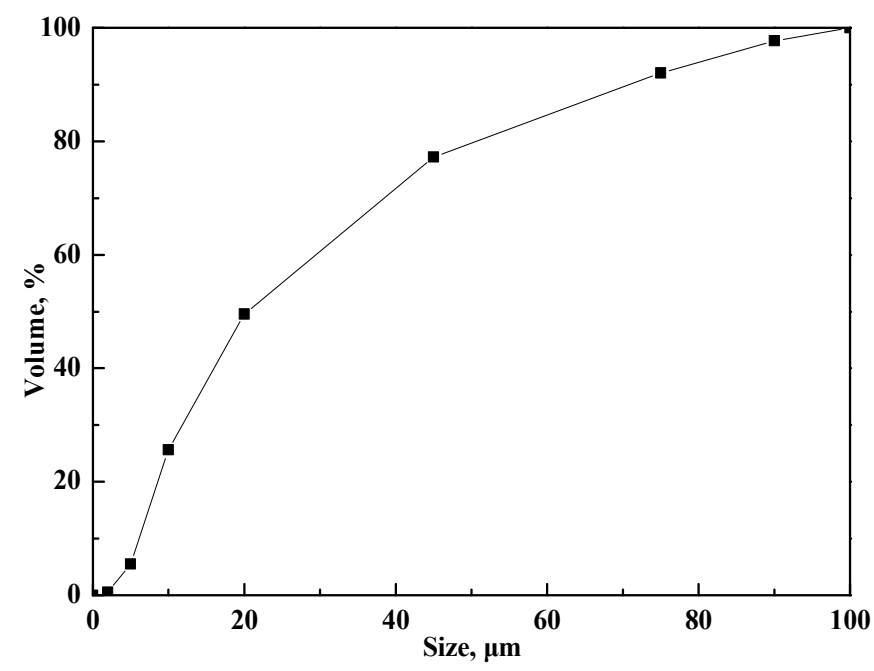

Figure 2. Size distribution of actual molybdenum ores.

Table 1. Element content analysis of molybdenite by XRF.

\begin{tabular}{ccccc}
\hline Elements & Mo & $\mathrm{S}$ & $\mathrm{SiO}_{2}$ & $\mathrm{Fe}_{2} \mathrm{O}_{3}$ \\
\hline Amount $(\%)$ & 59.4 & 39.69 & 0.79 & 0.12 \\
\hline
\end{tabular}

Table 2. Compositions of molybdenum ore, shown as a percentage.

\begin{tabular}{cccccccc}
\hline $\mathbf{M o}$ & $\mathbf{F e}$ & $\mathbf{S}$ & $\mathbf{P}$ & $\mathbf{Z n}$ & $\mathbf{C a F}_{\mathbf{2}}$ & $\mathbf{C a O}$ & $\mathbf{A l}_{\mathbf{2}} \mathbf{O}_{\mathbf{3}}$ \\
\hline 0.048 & 3.98 & 0.20 & 0.03 & 0.03 & 0.47 & 12.37 & 7.89 \\
$\mathrm{SiO}_{2}$ & $\mathrm{~K} 2 \mathrm{O}$ & $\mathrm{Na}_{2} \mathrm{O}$ & $\mathrm{MnO}_{2}$ & $\mathrm{TiO}_{2}$ & $\mathrm{MgO}$ & $\mathrm{Pb}$ & $\mathrm{C}$ \\
50.50 & 4.39 & 0.54 & 0.51 & 0.28 & 10.49 & 0.012 & 0.77 \\
\hline
\end{tabular}

The coal tar used was taken from a coal coking company in Shanxi Province, China. Kerosene and coal tar were mixed in a mass ratio of 1:1; the mixture was stirred using a magnetic stirrer for $60 \mathrm{~min}$, then the sample was allowed to settle and the upper liquid was poured out as a kerosene-coal tar collector (KCTC), as shown in Figure 3. The mass concentration of the extractive from the coal tar in the kerosene was about $15 \%$. Reagentgrade sodium hydroxide and hydrochloric acid, purchased from the Sinopharm Chemical Reagent Co., Ltd., Shanghai, China, were used to adjust the $\mathrm{pH}$ of the pulp. Kerosene and No. 2 oil were used as another collector and a frother, respectively. All experiments were conducted using deionized water, with a resistivity of $18.2 \mathrm{M} \Omega$ unless stated otherwise.

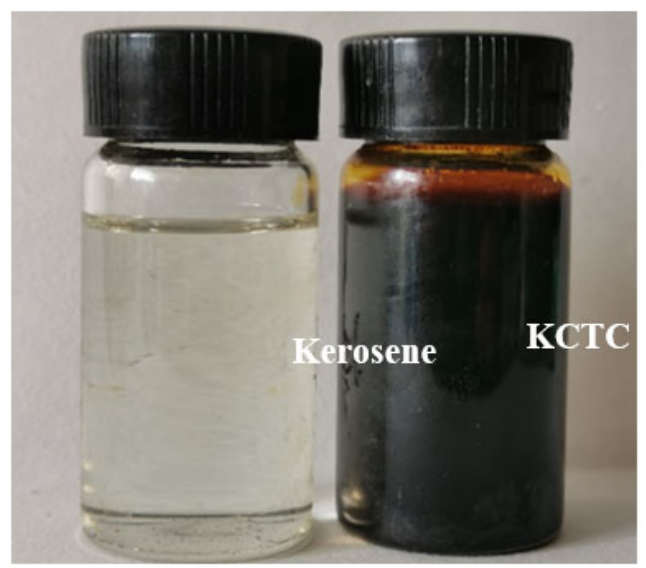

Figure 3. Collectors used in molybdenite flotation. 


\subsection{Flotation Experiments}

A micro-flotation machine with a $40 \mathrm{~mL}$ cell was used to carry out flotation experiments of single molybdenite, and $2.0 \mathrm{~g}$ molybdenite particles were weighed for each experiment. In the experiments, molybdenite particles were initially conditioned in deionized water for $120 \mathrm{~s}$ with a stirring speed of $1800 \mathrm{rpm}$. Then, the $\mathrm{pH}$ of the suspension was adjusted to 8.0 using $\mathrm{NaOH}$ or $\mathrm{HCl}$ stock solutions and kept under mixing conditions for $120 \mathrm{~s}$, after which the collector was added; $180 \mathrm{~s}$ later, No. 2 oil was added to the suspension for an additional $120 \mathrm{~s}$ of conditioning. Finally, the gas valve of the flotation machine was opened to collect froth for $300 \mathrm{~s}$ at an airflow rate of $60 \mathrm{~cm}^{3} / \mathrm{min}$. The flotation experiments were performed in either duplicate or triplicate.

The actual molybdenum ores were floated using an XFD-1.5 flotation machine with a $1.5 \mathrm{~L}$ cell, and the mass concentration of the pulp was a fixed consistency at $30 \%$. Kerosene and KCTC were used as collectors to compare the flotation efficiency. The impeller speed of the flotation machine was set at $2100 \mathrm{rpm}$ and the airflow rate was maintained at $0.30 \mathrm{~m}^{3} /\left(\mathrm{m}^{2} \cdot \mathrm{min}\right)$. The other flotation parameters were the same, with a flotation procedure of single molybdenite particles.

\subsection{Bubble-Particle Attachment Experiments}

The bubble-particle attachment test system is shown in Figure 4. For each test, $4.0 \mathrm{~g}$ of molybdenite particles were mixed with $200 \mathrm{~mL}$ deionized water in a square sample cell made from organic glass. A magnetic stirrer was used to disperse the molybdenite particles completely for $300 \mathrm{~s}$ at $400 \mathrm{rpm}$. Then, the liquid supernatant was poured out carefully after $120 \mathrm{~s}$ of sedimentation. The remaining molybdenite particles were thoroughly washed with deionized water thrice to make the suspension clear enough for photo collecting. In the attaching process, an air bubble of $2.5 \pm 0.1 \mathrm{~mm}$ in diameter was generated at the end of a capillary tube on a syringe, which was placed $4 \mathrm{~cm}$ below the liquid level, and $250 \mathrm{rpm}$ was used to drive the molybdenite particles to attach to the bubble. The bubble photos were recorded after 10,30,60,120,180, and $300 \mathrm{~s}$. The attaching angle $\theta$ and bubble surface coverage were both employed to evaluate the attaching behaviors of particles to the bubble, which method is widely accepted [21-26]. Hence, the coverage surface area $\left(S_{p}\right)$ was used to evaluate the attaching behaviors of molybdenite particles on the bubble; it is calculated approximatively using the following formula:

$$
S_{p} \approx \pi D^{2}\left(\sin \frac{\theta}{4}\right)^{2}
$$

where $S_{p}$ is the coverage surface area, namely, the surface area of a bubble coated with molybdenite particles, $D$ is the diameter of the bubble, and $\theta$ is the attaching angle.

Relative mineralization area $(\eta)$ is defined as the ratio of the coverage area $\left(S_{p)}\right.$ to the entire bubble surface area that could be coated by particles $\left(S_{0}\right)$ in the following formula:

$$
\eta=\frac{S_{p}}{S_{0}} \times 100
$$

\subsection{X-ray Photoelectron Spectroscopy (XPS)}

Freshly prepared molybdenite particles were used for X-ray photoelectron spectroscopy (XPS) measurement. Firstly, $2.0 \mathrm{~g}$ of $-20 \mu \mathrm{m}$ molybdenite particles were placed into $100 \mathrm{~mL}$ of deionized water in a $250 \mathrm{~mL}$ beaker, with or without $500 \mathrm{mg} / \mathrm{L}$ kerosene or KCTC, with a magnetic stirrer at a stirring speed of $500 \mathrm{rpm}$ for $60 \mathrm{~min}$. Secondly, the treated sample was filtered and freeze-dried for the subsequent XPS analysis. Finally, the prepared samples were measured using an XPS setup (ESCALAB 250Xi; Thermo Scientific, Waltham, MA, USA) with an $\mathrm{Al} \mathrm{K \alpha}$ monochromatic X-ray source. The detailed principles of XPS measurement have been reported elsewhere [27-29]. All binding energy calibration 
was calibrated based on the neutral C1s peak at $284.8 \mathrm{eV}$ and the surface charging effects were analyzed using XPS Peak 4.1 software.

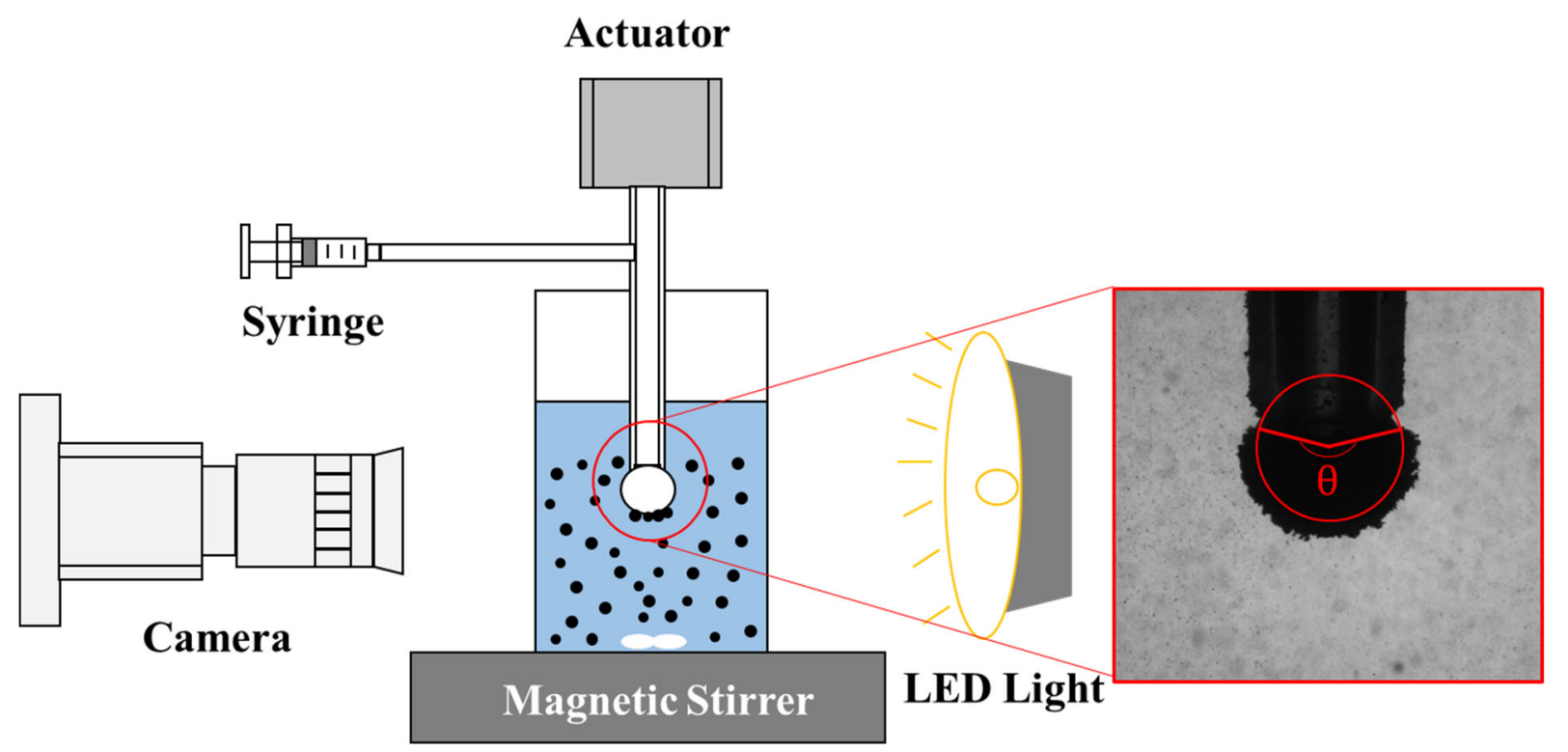

Figure 4. Schematic of bubble-particle attachment test system.

\subsection{Adsorption Measurement}

The adsorption of kerosene and KCTC onto molybdenite particles of different sizes was detected via a depletion technique. Briefly, $2.0 \mathrm{~g}$ molybdenite powders of the desired sizes were mixed with $100 \mathrm{~mL} 300 \mathrm{mg} / \mathrm{L}$ collector solution or deionized water in a $250 \mathrm{~mL}$ beaker for $2 \mathrm{~h}$ using a magnetic stirrer at $300 \mathrm{rpm}$, at $25^{\circ} \mathrm{C}$. Then, the suspension was centrifuged for $25 \mathrm{~min}$ at 10,000 rpm in a centrifuge to create the supernatant. The residual concentration of collectors in the supernatant was detected by determining total organic carbon using a Total Organic Carbon Analyzer (Shimadzu, Japan). Equations (3) and (4) were used to calculate adsorption amount per unit mass and per unit area, respectively:

$$
\begin{aligned}
\Gamma_{m} & =\frac{\left(C_{0}-C_{e}\right) V}{m} \\
\Gamma_{A} & =\frac{\left(C_{0}-C_{e}\right) V}{A}
\end{aligned}
$$

where $\Gamma_{m}$ is the adsorption amount per unit mass $(\mathrm{mg} / \mathrm{g}), \Gamma_{A}$ is the adsorption amount per unit area $\left(\mathrm{mg} / \mathrm{m}^{2}\right), C_{0}$ is the initial concentration of the collector solution $(\mathrm{mg} / \mathrm{L}), C_{0}$ is the equilibrium concentration of the collector solution $(\mathrm{mg} / \mathrm{L}), V$ is the volume of collector solution (L), and $A$ is the specific surface area of molybdenite powders $\left(\mathrm{m}^{2}\right)$.

\section{Results and Discussion}

\subsection{Bubble-Particle Attachment Analysis}

The attachment of molybdenite particles pretreated with or without collectors to a bubble was measured, and variations in the coverage area over time are shown in Figure 5. Due to the attachment to the wall of the cell and a lower settling velocity in the experiment process, clear photos cannot be captured for molybdenite particles with a size of $-20 \mu \mathrm{m}$. Thus, here, the attaching tests were only performed using molybdenite particles with a size of $-74+38 \mu \mathrm{m}$ and $-38+20 \mu \mathrm{m}$. As shown in Figure 6, the surface coverage of bubbles was shown to increase as a function of time, as more particles attached to the bubble. Moreover, the surface coverage was improved for molybdenite powders pretreated with kerosene or KCTC. The adsorption of kerosene or KCTC on molybdenite surfaces enhanced molybdenite particle attachment to the bubbles. It should be noted that better 
attaching performance was obtained in molybdenite particles pretreated with KCTC than in those pretreated with kerosene. Compared with kerosene, after pretreatment with KCTC, the bubble was almost fully covered after $120 \mathrm{~s}$ with molybdenite powders with a size of $-38+20 \mu \mathrm{m}$, and more molybdenite particles with a size of $-74+38 \mu \mathrm{m}$ and $-38+20 \mu \mathrm{m}$ were attached to the bubble. This meant that KCTC was beneficial in the attaching of molybdenite particles of both sizes to the bubble, especially in the case of the finer size of $-38+20 \mu \mathrm{m}$. It was deduced that the attaching performance of molybdenite particles with a size of $-20 \mu \mathrm{m}$ should also be improved by the use of KCTC. Molybdenite particles $(-74+38 \mu \mathrm{m})$ pretreated with $50 \mathrm{mg} / \mathrm{L} \mathrm{KCTC}$ solution.

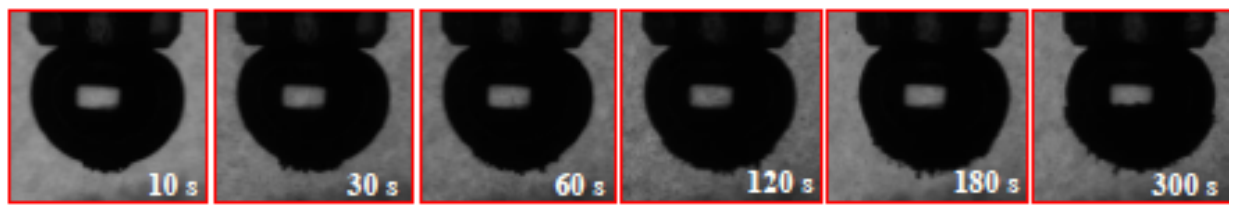

Molybdenite particles $(-38+20 \mu \mathrm{m})$ pretreated with deionized water
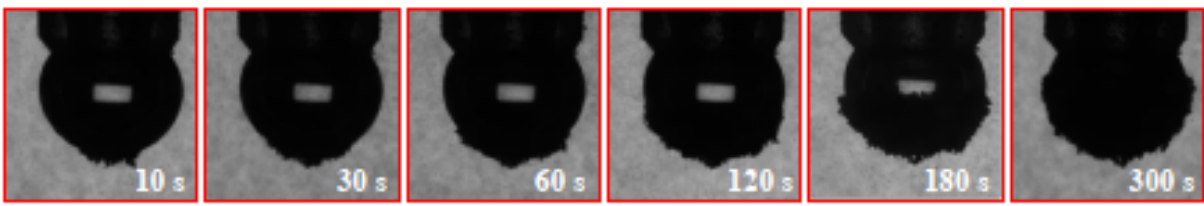

Molybdenite particles $(-38+20 \mu \mathrm{m})$ pretreated with $100 \mathrm{mg} / \mathrm{L}$ kerosene solution
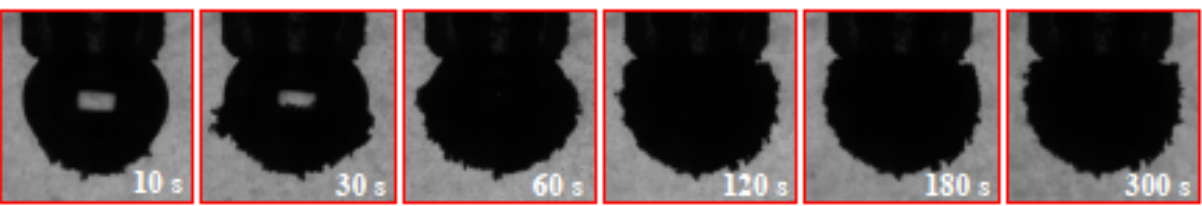

Molybdenite particles $(-38+20 \mu \mathrm{m})$ pretreated with $100 \mathrm{mg} / \mathrm{L} \mathrm{KCTC}$ solution
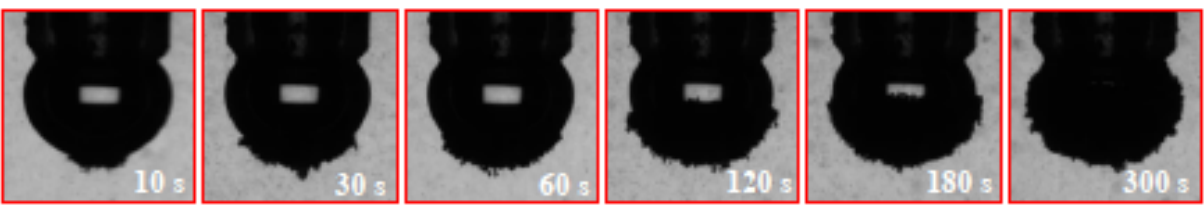

Molybdenite particles $(-74+38 \mu \mathrm{m})$ pretreated with deionized water
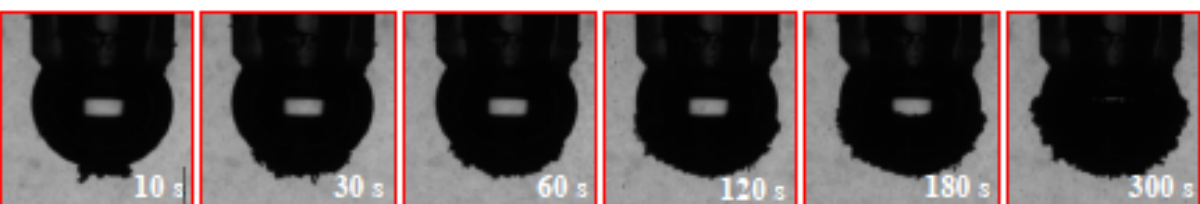

Molybdenite particles $(-74+38 \mu \mathrm{m})$ pretreated with $50 \mathrm{mg} / \mathrm{L}$ kerosene solution
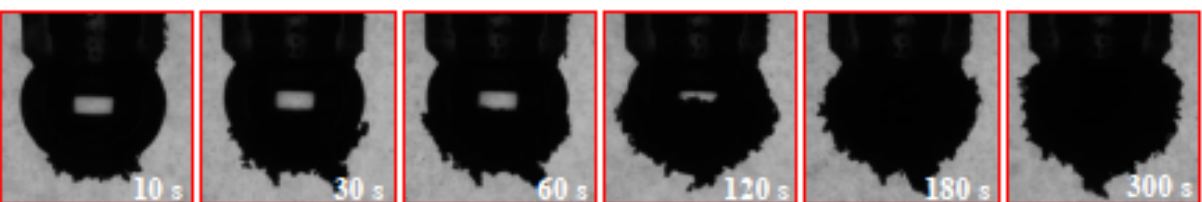

Molybdenite particles $(-74+38 \mu \mathrm{m})$ pretreated with $50 \mathrm{mg} / \mathrm{L} \mathrm{KCTC}$ solution

Figure 5. Attaching variations over time for different molybdenite powders, pretreated with or without collectors. 

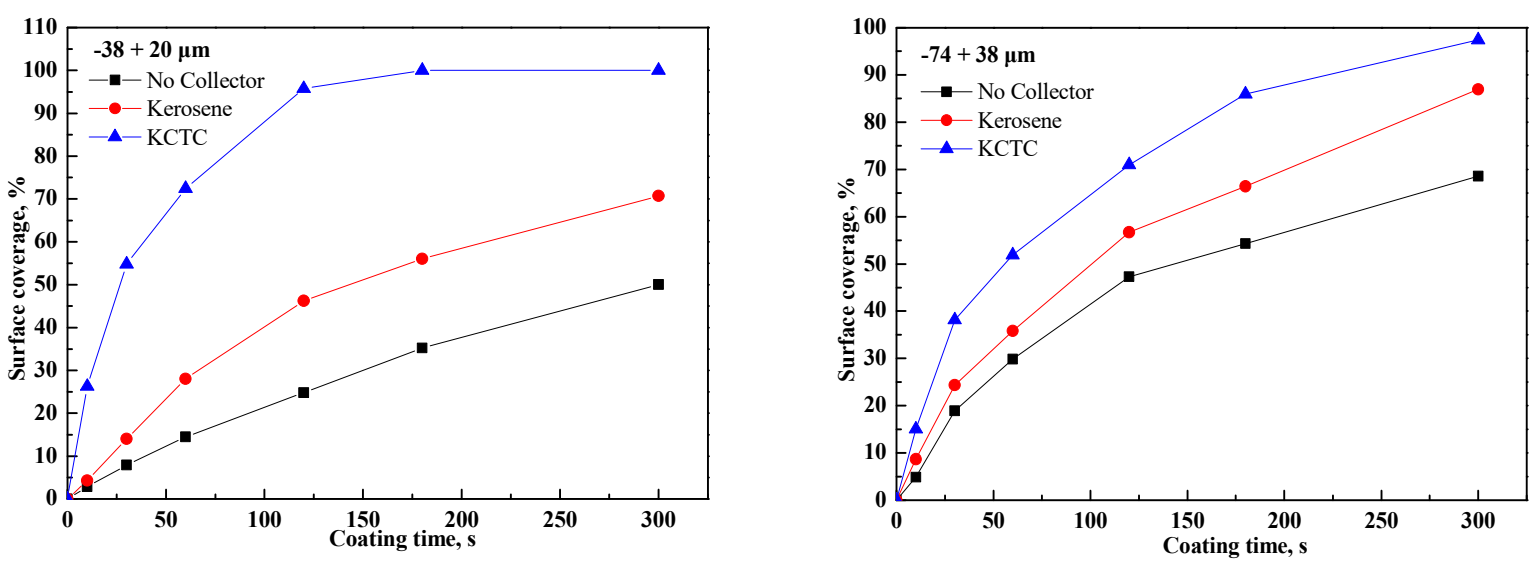

Figure 6. Surface coverage of bubbles with different molybdenite powders, as the function of different collectors.

Attaching kinetics were used to analyze the attaching rate of molybdenite particles on bubbles, which indicated the floatability of mineral particles [30]. The flotation kinetic models, the classical first-order model, and the first-order model with rectangular distribution were employed to fit the attaching kinetics of molybdenite particles to the bubble [30,31]. The fitting curves of the coverage area and results are shown in Figures 7 and 8 , and Table 3. The fitting parameters, maximum coverage area $S_{p \infty}$, and attaching rate constant $k_{a}$ were used to evaluate the attaching behaviors of different molybdenite particles to the bubble with or without collectors. It was concluded that both the classical first-order model and the first-order model with rectangular distribution fitted the experimental results well, as high $\mathrm{R}^{2}$ values indicated that the attaching experiments could offer evidence as to the flotation behavior of molybdenite. Higher $S_{p \infty}$ and $k_{a}$ values indicated better floatability in the flotation process [31,32]. The addition of both kerosene and KCTC increased the coverage area and attaching rates of molybdenite particles to bubbles. It should be noted that the attaching performances were much better when using the KCTC than those of kerosene. A more pronounced increase in coverage area and attaching rates was achieved for finer molybdenite particles with a size of $-38+20 \mu \mathrm{m}$, pretreated with $100 \mathrm{mg} / \mathrm{L} \mathrm{KCTC \text {, }}$ and the attaching equilibrium time was decreased from $300 \mathrm{~s}$ to around $120 \mathrm{~s}$ when fully covered. This indicates that KCTC may have a greater affinity for the finer molybdenite, which results in high attaching angles and rates.
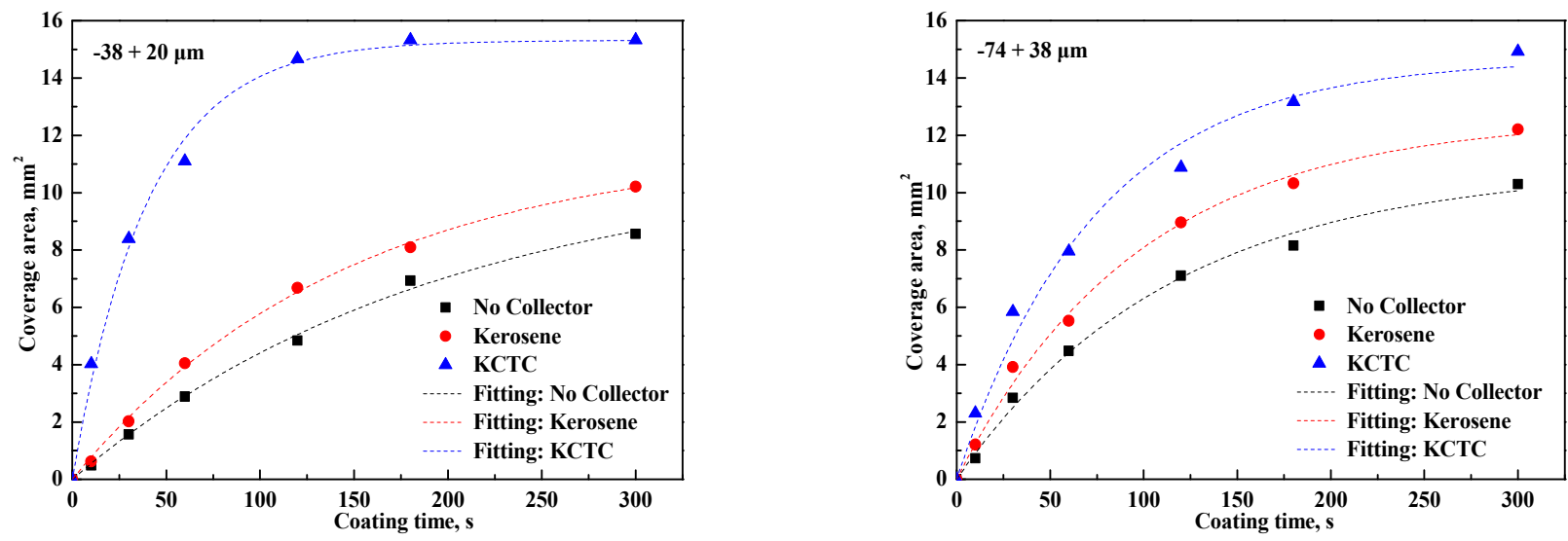

Figure 7. Attaching kinetics fitting of molybdenite particles to bubbles, using a classical first-order model. 

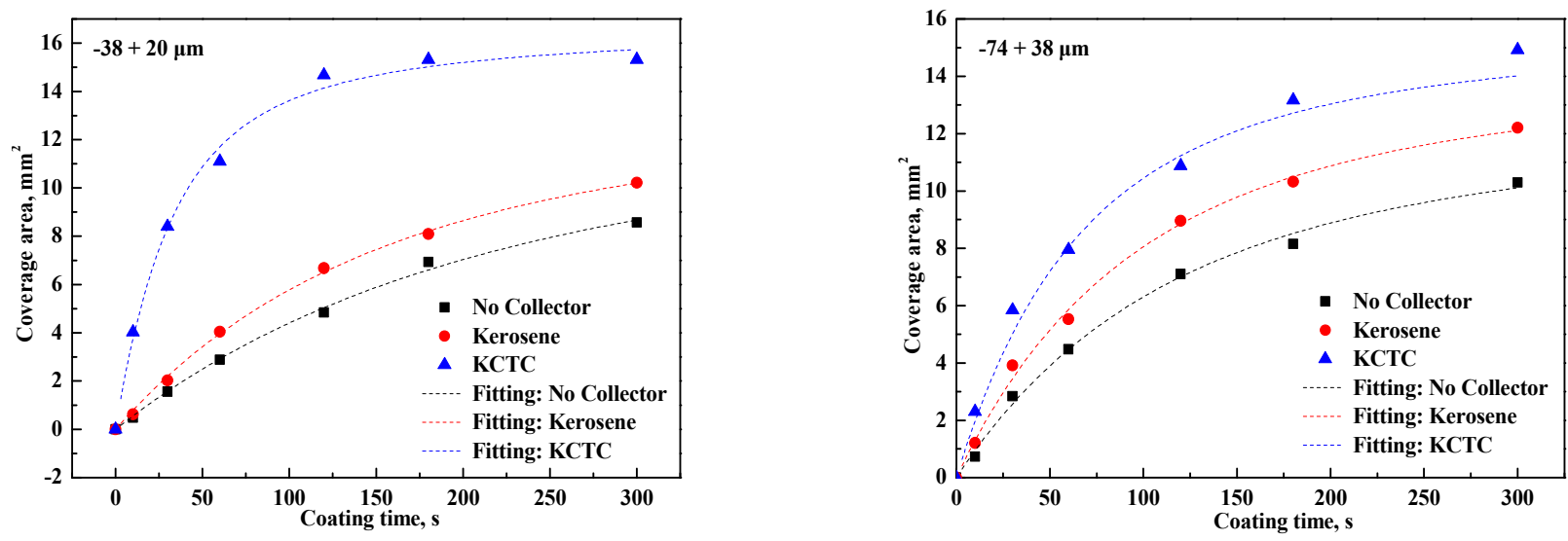

Figure 8. Attaching kinetics fitting of molybdenite particles to bubbles, using a first-order model with a rectangular distribution.

Table 3. Fitting results of the attaching kinetics of molybdenite particles to bubbles, with flotation kinetic models.

\begin{tabular}{|c|c|c|c|c|}
\hline Model & Samples & $S_{p \infty}$ & $k_{a}$ & $\mathbf{R}^{2}$ \\
\hline \multirow{6}{*}{$\begin{array}{l}\text { Classical first-order model } \\
\quad \theta=\theta_{\infty}\left(1-\exp \left(-k_{a} t\right)\right.\end{array}$} & $-38+20 \mu \mathrm{m}$ (No collector) & 11.07 & 0.0051 & 0.9973 \\
\hline & $-38+20 \mu \mathrm{m}$ (Kerosene) & 11.66 & 0.0069 & 0.9986 \\
\hline & $-38+20 \mu \mathrm{m}($ КCTC $)$ & 15.31 & 0.0250 & 0.9935 \\
\hline & $-74+38 \mu \mathrm{m}$ (No collector) & 10.86 & 0.0087 & 0.9946 \\
\hline & $-74+38 \mu \mathrm{m}$ (Kerosene) & 12.60 & 0.0103 & 0.9951 \\
\hline & $-74+38 \mu \mathrm{m}(\mathrm{KCTC})$ & 14.65 & 0.0134 & 0.9852 \\
\hline \multirow{6}{*}{$\begin{array}{l}\text { First-order model with rectangular } \\
\text { distribution } \\
\qquad \theta=\theta_{\infty}\left(1-\frac{1}{k_{a} \mathrm{t}}\left(1-\exp \left(-k_{a} \mathrm{t}\right)\right)\right)\end{array}$} & $-38+20 \mu \mathrm{m}$ (No collector) & 13.71 & 0.0083 & 0.9970 \\
\hline & $-38+20 \mu \mathrm{m}$ (Kerosene) & 14.12 & 0.0117 & 0.9986 \\
\hline & $-38+20 \mu \mathrm{m}(\mathrm{KCTC})$ & 16.29 & 0.0526 & 0.9946 \\
\hline & $-74+38 \mu \mathrm{m}$ (No collector) & 12.85 & 0.0154 & 0.9960 \\
\hline & $-74+38 \mu \mathrm{m}$ Kerosene) & 14.73 & 0.0187 & 0.9964 \\
\hline & $-74+38 \mu \mathrm{m}(\mathrm{KCTC})$ & 16.02 & 0.0268 & 0.9870 \\
\hline
\end{tabular}

\subsection{Adsorption of Kerosene and KCTC on Molybdenite Particles}

As reported, the differences in mineral surfaces before and after reagent adsorption can be determined by XPS via semi-quantitative analysis [29]. To initially and rapidly identify the surface-chemistry changes of samples in the absence and presence of collectors, XPS was used to measure the molybdenite particles. The XPS wide-energy spectra of molybdenite particles pretreated with deionized water (MD), molybdenite particles pretreated with kerosene (MK), and molybdenite particles pretreated with KCTC (MKC) are shown in Figure 9, and the semi-quantitative results of surface chemical composition are listed in Table 4. Obviously, compared with MD, the organic carbon contents on the MK and MKC surfaces were much higher, and the inorganic mineral element (Mo, S) contents decreased to lower levels. A more pronounced increase in organic carbon was achieved by KCTC. This indicated that the KCTC had more affinity for the molybdenite particles, which agreed well with the results from the attaching tests.

Moreover, the adsorption amounts of kerosene and KCTC on molybdenite particles were measured further using a depletion technique and the results are shown in Figure 10. As the particle size decreased, the adsorption amount of kerosene and KCTC on molybdenite particle surfaces per unit of mass increased with the increase in the specific surface area. It should be noted that the adsorption amount of kerosene per unit area decreased, while the adsorption amount of KCTC per unit area increased slightly. As the molybdenite size decreased, more polar edges were exposed and the edge/face ratio increased [1,33-35]. As reported, there were more benzene rings in this composite collector [20], which adsorbed molybdenite particles with a high edge/face ratio to a significant degree [19]. Thereby, greater adsorption amounts of KCTC on fine-grained molybdenite were achieved. The results showed good consistency with the XPS results. 


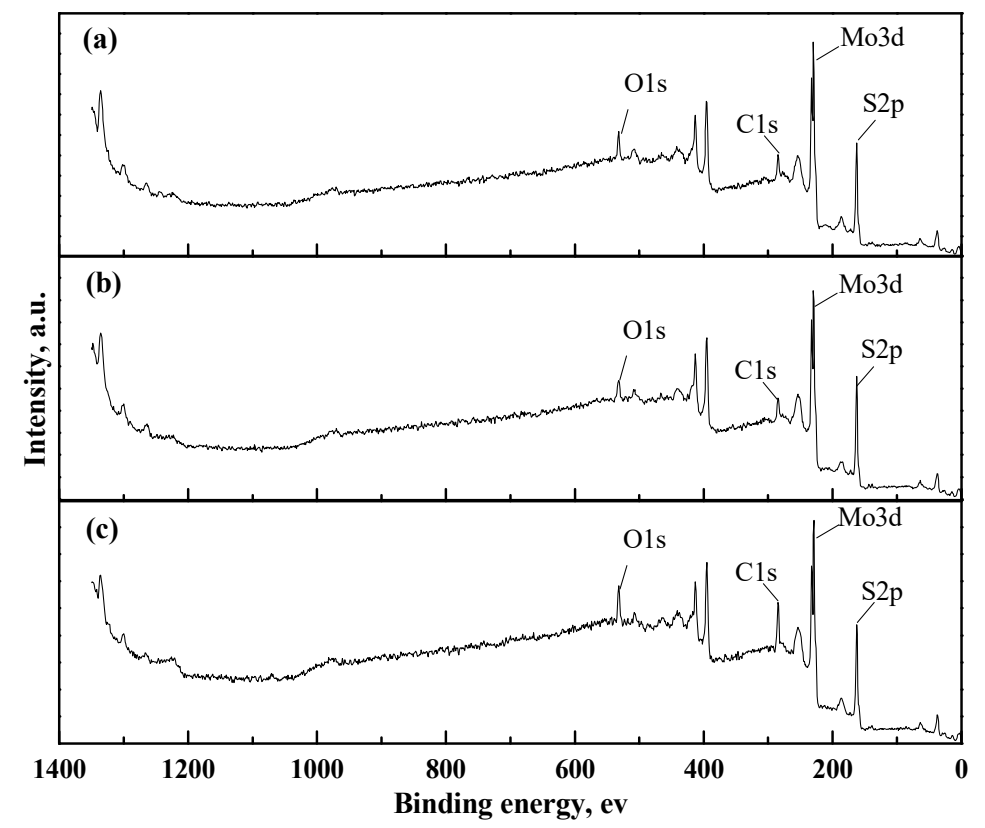

Figure 9. XPS wide-scan spectra of coal samples: (a) MD, (b) MK, (c) MKC.

Table 4. Surface chemical composition of coal samples (semiquantitative).

\begin{tabular}{ccccc}
\hline Samples & C (\%) & O (\%) & Mo (\%) & S (\%) \\
\hline MN & 21.04 & 15.19 & 20.05 & 43.72 \\
MK & 26.97 & 15.17 & 19.34 & 38.52 \\
MKC & 32.43 & 15.32 & 15.85 & 36.40 \\
\hline
\end{tabular}
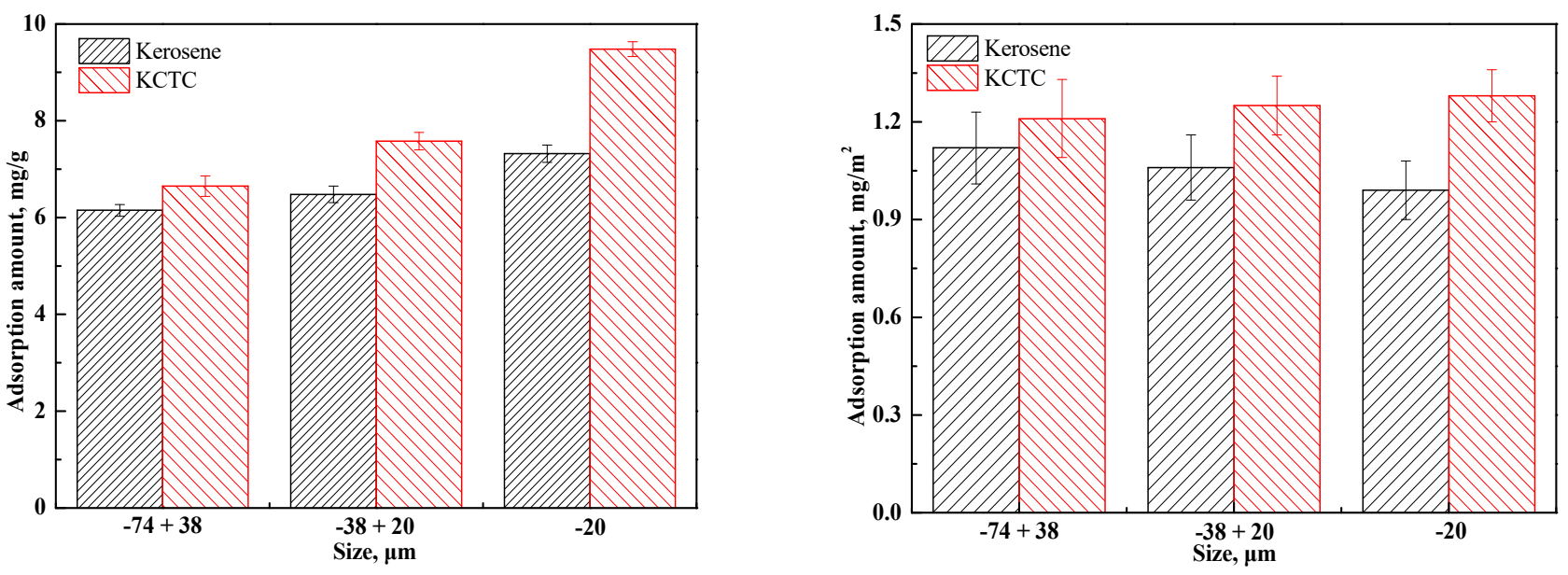

Figure 10. Adsorption amount of kerosene and KCTC on molybdenite particles of different sizes.

\subsection{Flotation Results}

The flotation performance of molybdenite particles was investigated, using kerosene and KCTC as collectors. As shown in Figure 11, the flotation recoveries of molybdenite particles with a size of $-74+38 \mu \mathrm{m}$ and $-38+20 \mu \mathrm{m}$ were much higher than those with a size of $-20 \mu \mathrm{m}$, using both kerosene and KCTC as collectors. There were significant improvements to the flotation of molybdenite particles of three different sizes with the addition of KCTC. It should be noted that a more pronounced recovery enhancement for molybdenite particles with a size of $-20 \mu \mathrm{m}$ was achieved. This conclusion is consistent with the results of the attaching experiments and adsorption measurement. More particles 
attached to the bubbles due to greater KCTC adsorption, leading to better mineralization of fine molybdenite particles, which resulted in a better flotation recovery rate [36].
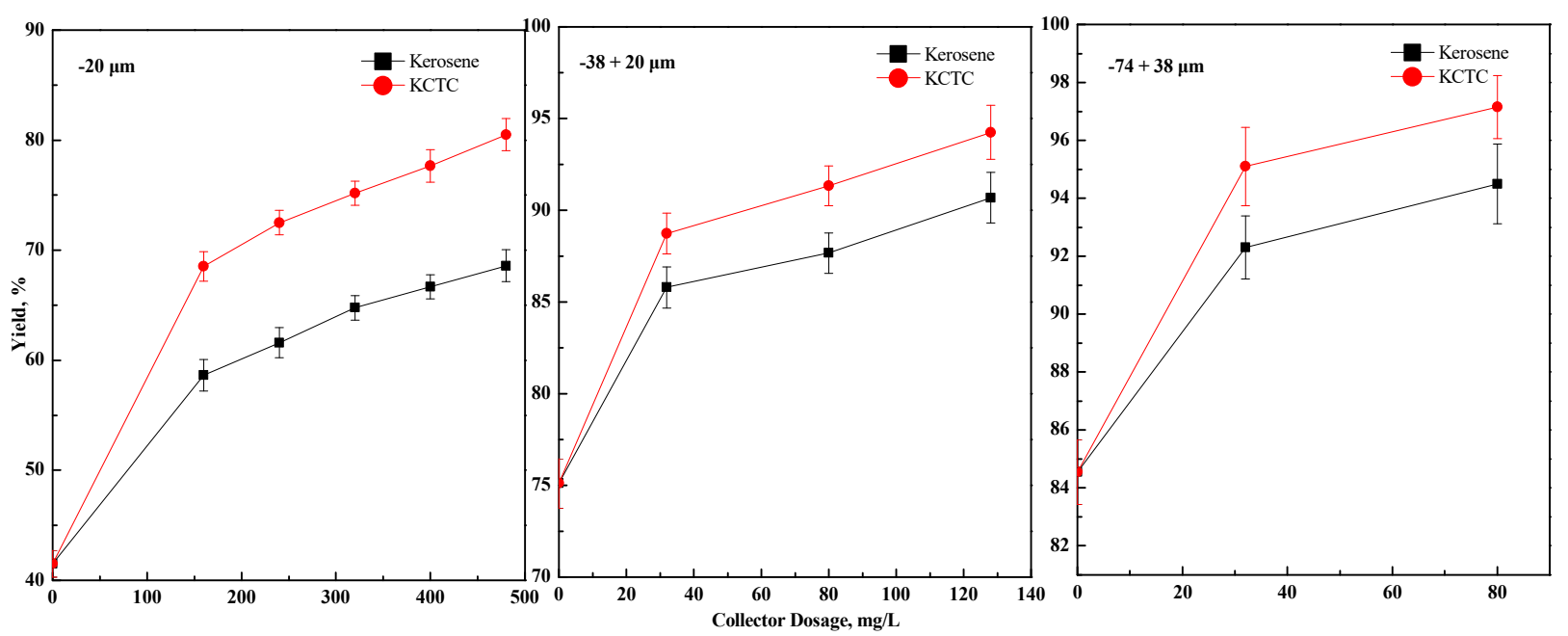

Figure 11. Flotation performance of kerosene and KCTC, regarding the flotation of molybdenite particles of different sizes.

The flotation performance of actual molybdenum ores was explored using kerosene and KCTC as collectors, and the results are shown in Figure 12. It is easy to see that KCTC improved the recovery rate of molybdenum. In addition, the flotation selectivity has been improved. It can be concluded that KCTC is a potential collector in the separation of low-grade molybdenum ores, and more studies should be conducted regarding the further use of KCTC in industrial practice.

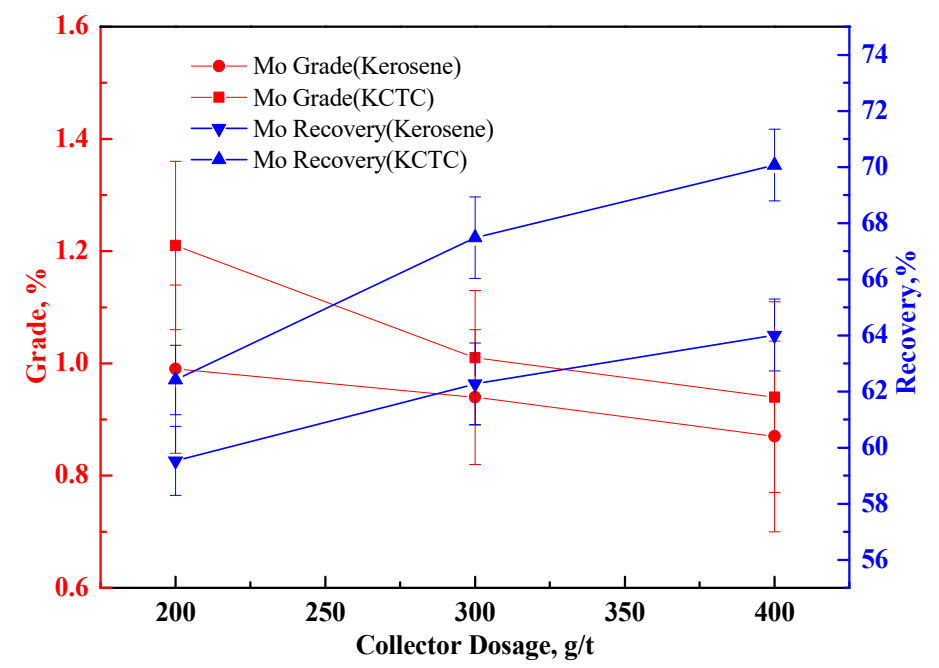

Figure 12. Effects of kerosene and KCTC on the flotation of actual molybdenum ores.

\section{Conclusions}

The influence of KCTC on the flotation performance of fine particles of molybdenite of different sizes was explored. It was found that KCTC significantly improved the coverage area and attaching rates of molybdenite particles of different sizes on bubbles, especially for a particle size of $-38+20 \mu \mathrm{m}$. KCTC was more susceptible to adsorbing molybdenite particles, and higher adsorption amounts of KCTC on molybdenite particles were achieved than with the use of kerosene. The flotation results further proved that KCTC improved the recovery of Mo from single molybdenite particles and actual molybdenum ores, and the flotation selectivity of actual molybdenum ores was also enhanced. It was proved that KCTC is an effective and potential collector for finely disseminated molybdenum ores. Further studies on the component analysis of KCTC, the mix ratios of kerosene and coal 
bar, and the flotation of actual molybdenum ores should be conducted to optimize this mixed collector system for industrial practice.

Author Contributions: S.L.: conceptualization, methodology, software, validation, supervision, writing_-original draft preparation, writing—review and editing, and funding acquisition; L.G. and Y.C. (Yijun Cao): conceptualization, methodology, software, writing-review and editing, and supervision; Y.C. (Yande Chao), L.S., L.L. and N.C.: investigation, formal analysis, and data curation. All authors have read and agreed to the published version of the manuscript.

Funding: This research was funded by the Fundamental Research Funds for the Central Universities (2019QNA11) and the National Nature Science Foundation of China (51904299).

Data Availability Statement: Not applicable.

Conflicts of Interest: The authors declare no conflict of interest.

\section{References}

1. Li, H.; He, T.; Wan, H.; Han, Y.; Guo, Y.; Jin, J. Insights into Selection of the Auxiliary Collector and Its Applicability Analysis for Improving Molybdenite Flotation. Minerals 2021, 11, 528. [CrossRef]

2. Yin, Z.; Sun, W.; Hu, Y.; Liu, R.; Jiang, W.; Zhang, C.; Guan, Q.; Zhang, C. Synthesis of acetic acid- (hydrazinylthioxomethyl)thio -sodium and its application on the flotation separation of molybdenite from galena. J. Ind. Eng. Chem. 2017, 52, 82-88. [CrossRef]

3. Bulatovic, S. Handbook of Flotation Reagents: Chemistry, Theory and Practice: Flotation of Sulfide Ores; Elsevier Science \& Technology: Amsterdam, The Netherlands, 2007.

4. Liu, G.; Lu, Y.; Zhong, H.; Cao, Z.; Xu, Z. A novel approach for preferential flotation recovery of molybdenite from a porphyry copper-molybdenum ore. Miner. Eng. 2012, 36-38, 37-44. [CrossRef]

5. Park, I.; Hong, S.; Jeon, S.; Ito, M.; Hiroyoshi, N. A Review of Recent Advances in Depression Techniques for Flotation Separation of Cu-Mo Sulfides in Porphyry Copper Deposits. Metals 2020, 10, 1269. [CrossRef]

6. Castro, S.; Lopez-Valdivieso, A.; Laskowski, J. Review of the flotation of molybdenite. Part I: Surface properties and floatability. Int. J. Miner. Process. 2016, 148, 48-58. [CrossRef]

7. Castillo, I.; Gutierrez, L.; Hernandez, V.; Diaz, E.; Ramirez, A. Hemicelluloses monosaccharides and their effect on molybdenite flotation. Powder Technol. 2020, 373, 758-764. [CrossRef]

8. Li, S.; Gao, L.; Wang, J.; Zhou, H.; Liao, Y.; Xing, Y.; Gui, X.; Cao, Y. Polyethylene oxide assisted separation of molybdenite from quartz by flotation. Miner. Eng. 2021, 162, 106765. [CrossRef]

9. Li, S.; Ma, X.; Wang, J.; Xing, Y.; Gui, X.; Cao, Y. Effect of polyethylene oxide on flotation of molybdenite fines. Miner. Eng. 2020, 146, 106146. [CrossRef]

10. Lin, Q.; Gu, G.; Wang, H.; Liu, Y.; Fu, J.; Wang, C. Flotation mechanisms of molybdenite fines by neutral oils. Int. J. Miner. Met. Mater. 2018, 25, 1-10. [CrossRef]

11. Kainuma, Y.; Uyeda, R. On the Structure of Adsorbed Organic Long-Chain Molecules on the Clevage Surface of Molybdenite. J. Phys. Soc. Jpn. 1950, 5, 199-200. [CrossRef]

12. Groszek, A. Preferential Adsorption of Long-chain Normal Paraffins on $\mathrm{MoS}_{2}, \mathrm{WS}_{2}$ and Graphite from n-Heptane. Nature 1964, 204, 680. [CrossRef]

13. Zanin, M.; Ametov, I.; Grano, S.; Zhou, L.; Skinner, W. A study of mechanisms affecting molybdenite recovery in a bulk copper/molybdenum flotation circuit. Int. J. Miner. Process. 2009, 93, 256-266. [CrossRef]

14. Hosseini, S.; Forssberg, E. Physicochemical studies of smithsonite flotation using mixed anionic/cationic collector. Miner. Eng. 2007, 20, 621-624. [CrossRef]

15. Shu, K.; Xu, L.; Wu, H.; Xu, Y.; Luo, L.; Yang, J.; Tang, Z.; Wang, Z. In Situ Adsorption of Mixed Anionic/Cationic Collectors in a Spodumene-Feldspar Flotation System: Implications for Collector Design. Langmuir 2020, 36, 8086-8099. [CrossRef]

16. Wang, J.; Gao, Z.; Gao, Y.; Hu, Y.; Sun, W. Flotation separation of scheelite from calcite using mixed cationic/anionic collectors. Miner. Eng. 2016, 98, 261-263. [CrossRef]

17. Xu, L.; Jiao, F.; Jia, W.; Pan, Z.; Hu, C.; Qin, W. Selective flotation separation of spodumene from feldspar using mixed anionic/nonionic collector. Colloids Surf. A Physicochem. Eng. Asp. 2020, 594, 124605. [CrossRef]

18. Wei, Q.; Feng, L.; Dong, L.; Jiao, F.; Qin, W. Selective co-adsorption mechanism of a new mixed collector on the flotation separation of lepidolite from quartz. Colloids Surf. A Physicochem. Eng. Asp. 2021, 612, 125973. [CrossRef]

19. He, T.; Li, H.; Jin, J.; Peng, Y.; Wang, Y.; Wan, H. Improving fine molybdenite flotation using a combination of aliphatic hydrocarbon oil and polycyclic aromatic hydrocarbon. Results Phys. 2019, 12, 1050-1055. [CrossRef]

20. Li, Y.; Xia, W.; Peng, Y.; Xie, G. A novel coal tar-based collector for effective flotation cleaning of low rank coal. J. Clean. Prod. 2020, 273, 123172. [CrossRef]

21. Sun, L.; Xing, Y.; Yang, H.; Cao, Y.; Gui, X. A New Experimental Approach to Evaluate Coal Particles Floatability: Bubble-Particle Attachment and Detachment Kinetics. ACS Omega 2020, 5, 16733-16738. [CrossRef] 
22. $\mathrm{Wu}, \mathrm{J} . ;$ Chen, L.; Zheng, N.; Sun, Z. Experimental investigation of the attachment of unburned carbon in coal fly ash to a stationary air bubble in aqueous solutions. Fuel 2021, 285, 119080. [CrossRef]

23. Chu, P.; Mirnezami, M.; Finch, J. Quantifying particle pick up at a pendant bubble: A study of non-hydrophobic particle-bubble interaction. Miner. Eng. 2014, 55, 162-164. [CrossRef]

24. Nikolaev, A. Flotation recovery of toner containing iron oxide from water suspension. Miner. Eng. 2019, 144, 106027. [CrossRef]

25. Wang, P.; Reyes, F.; Cilliers, J.; Brito-Parada, P. Evaluation of collector performance at the bubble-particle scale. Miner. Eng. 2020, 147, 106140. [CrossRef]

26. Zhu, C.; Xing, Y.; Xia, Y.; Wang, Y.; Li, G.; Gui, X. Flotation intensification of low-rank coal using a new compound collector. Powder Technol. 2020, 370, 197-205. [CrossRef]

27. Miki, H.; Hirajima, T.; Muta, Y.; Suyantara, G.; Sasaki, K. Effect of Sodium Sulfite on Floatability of Chalcopyrite and Molybdenite. Minerals 2018, 8, 172. [CrossRef]

28. Lin, S.; Liu, R.; Sun, W.; Hu, Y.; Han, H. Effect of $\mathrm{H}_{2} \mathrm{O}_{2}$ on the Separation of Mo-Bi-Containing Ore by Flotation. Minerals 2018, 8, 402. [CrossRef]

29. Yin, Z.; Sun, W.; Hu, Y.; Zhang, C.; Guan, Q.; Zhang, C. Separation of Molybdenite from Chalcopyrite in the Presence of Novel Depressant 4-Amino-3-thioxo-3,4dihydro-1,2,4-triazin-5(2H)-one. Minerals 2017, 7, 146. [CrossRef]

30. Xing, Y.; Xu, M.; Guo, F.; Luo, J.; Zhang, Y.; Cao, Y.; Gui, X. Role of different types of clay in the floatability of coal: Induction time and bubble-particle attachment kinetics analysis. Powder Technol. 2019, 344, 814-818. [CrossRef]

31. Yang, H.; Xing, Y.; Sun, L.; Cao, Y.; Gui, X. Kinetics of bubble-particle attachment and detachment at a single-bubble scale. Powder Technol. 2020, 370, 251-258. [CrossRef]

32. Ofori, P.; O’Brien, G.; Hapugoda, P.; Firth, B. Distributed flotation kinetics models-A new implementation approach for coal flotation. Miner. Eng. 2014, 66-68, 77-83. [CrossRef]

33. Wan, H.; Yi, P.; Qu, J.; Bu, X.; Yang, W.; Li, H. Adsorption Behaviors of Straight-Chain Alkanes on a Molybdenite 001/100 Surface: A Molecular Dynamics Study. Minerals 2021, 11, 489. [CrossRef]

34. Yang, B.; Song, S.; Lopez-Valdivieso, A. Effect of Particle Size on the Contact Angle of Molybdenite Powders. Miner. Process. Extr. Met. Rev. 2013, 35, 208-215. [CrossRef]

35. Li, W.; Li, Y.; Wei, Z.; Xiao, Q.; Song, S. Fundamental Studies of SHMP in Reducing Negative Effects of Divalent Ions on Molybdenite Flotation. Minerals 2018, 8, 404. [CrossRef]

36. Xing, Y.; Li, C.; Gui, X.; Cao, Y. Interaction Forces between Paraffin/Stearic Acid and Fresh/Oxidized Coal Particles Measured by Atomic Force Microscopy. Energy Fuels 2017, 31, 3305-3312. [CrossRef] 